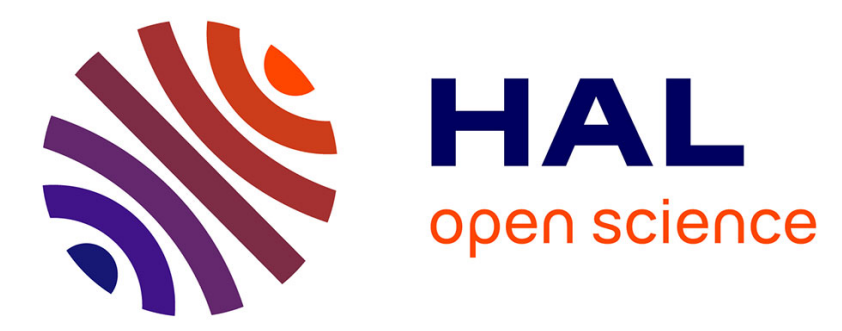

\title{
Cadmium-containing granules in kidney tissue of the Atlantic white-sided dolphin (Lagenorhyncus acutus) off the Faroe Islands
}

Isabelle Gallien, Florence Caurant, Monique Bordes, Paco Bustamante, Pierre Miramand, B. Fernandez, N. Quellard, P. Babin

\section{To cite this version:}

Isabelle Gallien, Florence Caurant, Monique Bordes, Paco Bustamante, Pierre Miramand, et al.. Cadmium-containing granules in kidney tissue of the Atlantic white-sided dolphin (Lagenorhyncus acutus) off the Faroe Islands. Comparative Biochemistry and Physiology - Part C: Comparative Pharmacology, 2001, 130 (3), pp.389 -395. 10.1016/S1532-0456(01)00265-4 . hal-00911065v2

\section{HAL Id: hal-00911065 \\ https://hal.science/hal-00911065v2}

Submitted on 22 Dec 2013

HAL is a multi-disciplinary open access archive for the deposit and dissemination of scientific research documents, whether they are published or not. The documents may come from teaching and research institutions in France or abroad, or from public or private research centers.
L'archive ouverte pluridisciplinaire HAL, est destinée au dépôt et à la diffusion de documents scientifiques de niveau recherche, publiés ou non, émanant des établissements d'enseignement et de recherche français ou étrangers, des laboratoires publics ou privés. 
Cadmium-containing granules in kidney tissue of the Atlantic white-sided dolphin (Lagenorhyncus acutus) off the Faroe Islands

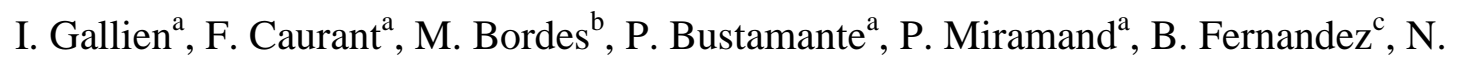
Quellard $^{\mathrm{c}}$, P. Babin ${ }^{\mathrm{c}}$

a Laboratoire de Biologie et Environnement Marins, EA 3168, Université de La Rochelle, 22, av. Michel Crépeau, 17042 La Rochelle cedex, France

${ }^{\mathrm{b}}$ Centre Commun d'Analyses, Université de la Rochelle, Perspectives de L'Océan, 17042 La Rochelle cedex, France

c Microscopie Electronique, Anatomie Pathologique, CHU La Milétrie, BP 577, 86021 Poitiers cedex, France

* Corresponding author.

Tel.: +33-5-46-50-02-91

Fax: +33-5-46-50-02-94.

E-mail address: fcaurant@univ-lr.fr 
Abstract: Top predators from the northern sub-polar and polar areas exhibit high cadmium concentrations in their tissues. In the aim to reveal possible adverse effects, samples of five Atlantic white-sided dolphins Lagenorhyncus acutus have been collected on the occasion of the drive fishery in the Faroe Islands, for ultrastructural investigations and energy dispersive X-ray microanalyses. Cadmium concentrations were less than the limit of detection in both immature individuals and ranged from 22.7 to $31.1 \mu \mathrm{g} \mathrm{g}^{-1}$ wet weight in the mature individuals. Two individuals with the highest cadmium concentrations exhibited electron dense mineral concretions in the basal membranes of the proximal tubules. They are spherocrystals made up of numerous strata mineral deposit of calcium and phosphorus together with cadmium. Cadmium has been detected with a molar ratio of $\mathrm{Ca}: \mathrm{Cd}$ of 10:1 in the middle of these concretions. To our knowledge, this is the first report of such granules in a wild vertebrate. The role of these granules in the detoxification of the metal and the possible pathological effects are considered.

Keywords: Cd; Ultrastructural investigations; Energy dispersive X-ray (EDX) detection; Spherocrystals; Atlantic white-sided dolphin; Faroe Islands; Light microscopy; Detoxification processes; Pathological effects 


\section{Introduction}

Kidney lesions related to cadmium and mercury exposure have been reported both in humans (Fowler, 1992; Elinder and Järup, 1996; Clarkson, 1997) and wildlife species such as seabird (Nicholson and Osborn, 1983, 1984; Nicholson et al., 1983). Thus, tubular dysfunction in human already appears when cadmium concentrations in the kidney cortex reach $50 \mu \mathrm{g} \mathrm{g}^{-1}$ (Elinder and Järup, 1996). Since marine mammals are relatively long-lived species and occupy the higher trophic levels, they are expected to accumulate relatively high metal levels. Moreover, cadmium levels found in the Arctic fauna are often much higher than in animals from temperate regions (Wagemann et al., 1990; Dietz et al., 1996, 1998). Some of the highest cadmium levels have been found in marine mammals from the Faroe Islands (Julshamn et al., 1987; Caurant et al., 1994), partly due to the consumption of highly concentrated cephalopods (Bustamante et al., 1998). These levels were higher in more than $75 \%$ of the population of pilot whales than the critical concentration of $50 \mu \mathrm{g} \mathrm{g}^{-1}$ wet wt. (Caurant and Amiard-Triquet, 1995). As no pathological effect study had been carried out previously on Arctic cetaceans, a study was initiated in august 1997 on white-sided dolphin (Lagenorhyncus acutus) caught in a drive fishery of the Faroe Islands, which is a great opportunity to sample very fresh tissue on numerous individuals at different stages of the life cycle. All the sampling and fixation steps were made on field. Cadmium, copper, mercury, selenium and zinc in liver, muscle, gonads and kidney have been analysed by absorption spectrophotometry (unpublished data). Histological and ultrastructural investigations of the kidney tissue have been carried out in five individuals, using light and electron microscopy, and X-ray microanalysis.

\section{Materials and methods}

\subsection{Sampling}

During a drive fishery in August 1997 in the Faroe Islands, a school of 150 Atlantic whitesided dolphins has been captured. Kidney tissue was sampled in five dolphins both for metal determination and histological investigations. The characteristics of these individuals and the results of cadmium and mercury analysis are shown in Table 1. 


\subsection{Metal concentration determination}

Tissue samples were dried for several days at $60^{\circ} \mathrm{C}$ to constant weight. Two aliquots of approximately $300 \mathrm{mg}$ of each homogenised dry sample were heated with a mixture of $4 \mathrm{ml}$ of $65 \%$ supra-pure nitric acid and $200 \mu \mathrm{l}$ of $70 \%$ suprapure perchloric acid at $65^{\circ} \mathrm{C}$ until the solution was clear. Blanks were carried through the procedure in the same way as the samples. Cadmium was determined by atomic absorption spectrophotometry (AAS) using a Varian spectrophotometer Vectra 250 Plus with deuterium background correction. Mercury was determined by inductively coupled plasma mass spectrometric (ICP-MS) detection, using a Varian Ultramass 700. The detection limit for cadmium and mercury was 0.1 and $0.2 \mu \mathrm{g} \mathrm{g}^{-1}$ wet wt., respectively. As an analytical quality control, standards of the NRC Canada (Dogfish liver: DOLT-2) were analysed using the same procedure. Our results $\left(20.9 \pm 0.5 \mu \mathrm{g} \mathrm{g}^{-1}\right.$ wet wt. for $\mathrm{Cd}$ and $2.13 \pm 0.28 \mu \mathrm{g} \mathrm{g}^{-1}$ wet wt. for $\mathrm{Hg}$ ) were in good agreement with the certified values: $20.8 \pm 0.5 \mu \mathrm{g} \mathrm{g}^{-1}$ wet wt. for $\mathrm{Cd}$; and $2.14 \pm 0.28 \mu \mathrm{g} \mathrm{g}^{-1}$ wet wt. for $\mathrm{Hg}$.

\subsection{Light and electron microscopy}

Slices of kidney were prefixed in $10 \%$ formalin, then post-fixed in Bouin fixative. After deshydratation and clearing in toluene, they were embedded in paraffin. Sections $(7 \mu \mathrm{m})$ were stained with Azan for histopathological examination of the kidney cortex. Very small pieces of renal tissue were fixed on field in $4 \%$ glutaraldehyde in $0.4-\mathrm{M}$ cacodylate buffer, $\mathrm{pH}$ 7.3. In the laboratory, samples were post-fixed in $2 \%$ osmium tetroxyde in cacodylate $(0.4 \mathrm{M})$ for 30 min at room temperature, processed through a graded acetone series, embedded in Spurr and polymerized for 3 days at $70^{\circ} \mathrm{C}$. Semi-thin sections $(1 \mu \mathrm{m})$ were cut and stained with toluidine blue, APS and Marinozzi for light microscopy examination. Thin sections $(0.5 \mu \mathrm{m})$ were stained with uranyl acetate and lead citrate (Reynolds, 1963) and then examined with a JEOLJEM 1010 electron microscope (JEOL, Tokyo, Japan).

\subsection{X-Ray analysis}

Microanalysis were performed on non-stained thin sections with a Philips CM 120 electron microscope equipped with an EDAX X-ray detector at $120 \mathrm{kV}$. The energy dispersive X-rays (EDX) detector is positioned on the electron microscope, close to the sample in order to capture X-rays as they emerge from the beamed surface of the sample. Under typical 
operating conditions on the electron microscope, it is possible for the EDX system to detect approximately $0.5 \%$ of all the elements from carbon to uranium. Quantitative X-ray microanalysis was done in X-rays imaging mode on zones with many granules and in nanoprobe mode on different parts of the granules.

\section{Results}

\subsection{Metal concentrations in tissues}

Cadmium and mercury concentrations in the kidney samples are given in Table 1. Cadmium concentrations in the whole kidney were less than the detection limit in immature individuals and ranged from 22.7 to $31.1 \mu \mathrm{g} \mathrm{g}^{-1}$ wet wt. (106.8 to $149.1 \mu \mathrm{g} \mathrm{g}^{-1}$ dry wt.) in the mature individuals. The mercury concentrations ranged from 0.1 to $2.5 \mu \mathrm{g} \mathrm{g}^{-1}$ wet wt.

\subsection{Light microscopy observations}

The examination of kidney slices revealed a structure as described by Ridgway (1972) for cetacean kidney cortex. Morphological studies showed alterations in proximal tubule. They were mainly characterised by vacuolation, numerous lysosomes and tubular lumens filled by cytoplasmic debris. Some renal corpuscules showed little signs of abnormalities: a more pronounced coloration of the basal membrane, which shows its thickening; a swollen capillary loops; and some external debris (Fig. 1).

\subsection{Electron microscopy observations}

Cells in various stages of degeneration were observed within the same tubular profile, necrotic cells often neighbouring cells of normal appearance. Exfoliation of necrotic cells into the lumen of the tubules was also evident. In the proximal tubule cells, many lysosomes were common as well as small membrane bound vesicles, which were scattered evenly throughout the cytoplasm. Few normal mitochondria were observed. In many cases, they had swelling appearance or were totally degenerated. Very abundant granules of diameter up to $300 \mathrm{~nm}$ were observed in the basement membrane of the tubules of the individuals 1 and 3 (Fig. 2). They were composed of clustered spherical particles with well-defined shapes, which formed continuous rings. 


\subsection{X-Ray analysis}

These kidney granules have been investigated by EDX analysis. X-Ray imaging permitted to identify numerous strata mineral deposit of calcium $(\mathrm{Ca})$ and phosphate $(\mathrm{P})$. The nanoprobe analysis revealed the molar ratio of $\mathrm{Ca}: \mathrm{P}$ was $1: 1.6$, and the presence of cadmium traces in the middle of the concretions with a molar ratio of Ca:Cd of 10:1 (Table 2).

\section{Discussion}

In the Faroe Islands, several top predators such as the long-finned pilot whale Globicephala melas (Caurant et al., 1994) or seabirds (unpublished data) exhibit high cadmium concentrations. Levels in white-sided dolphins Lagenorhyncus acutus are lower than those of pilot whales from the same area, but much higher than those encountered in numerous dolphin species from lower latitudes (Law et al., 1991, 1992; Mackey et al., 1995; Holsbeek et al., 1998). Considering that $\mathrm{Cd}$ concentration in the kidney cortex is $50 \%$ higher than in the whole kidney (Tsalev and Saprianov, 1983) and that cadmium concentrates in the proximal tubular cells of the nephron, several individuals would reach $50 \mu \mathrm{g} \mathrm{g}^{-1}$ wet wt. in the cortex, the critical concentration established by Elinder and Järup (1996) and the question of the effects of toxic elements in wild animals is raised. Thus, an histopathological study of the kidney tissue has been initiated since renal damage is one of the most important effect of cadmium and the most frequently described non-neural effects of methyl mercury. The investigation of the kidney tissue in light microscopy has allowed to show abnormalities of some renal corpuscles, which could be the expression of a renal suffering (Fig. 1), without this being necessarily the cause of a damage to the functioning of the organ. The kidney has a large spare capacity in that not all nephrons are needed to be continuously functional. Moreover, the regenerative capacity of the kidney is very great. Nevertheless, they may be times in the life cycle when such damage could be more critical (e.g. breeding period when demands on essential metal are higher, or when food is short). Besides this, necrotic figures appeared, probably as a consequence of elapsed time between death and sampling, which could have reached 2 and $1 \mathrm{~h}$ more for the sampling time between the first and the last individual, respectively. This delay is sufficient to give rise to ischemic injury (Moore and Stegeman, 1996; Goujon et al., 1999) and could be the cause of the vacuolation.

The most important result concerns the ultrastructural investigations, which have shown calcium phosphate concretions in the basal membrane of the kidney tissue of two individuals 
(Fig. 2). Granules containing mercury and selenium have already been reported in the liver of marine mammals and birds (Martoja and Viale, 1977; Nigro and Leonzio, 1996), and the respiratory system of cetaceans (Rawson et al., 1995), but to our knowledge this is the first report of granules containing cadmium in a wild vertebrate. The occurrence of metalcontaining granules is well documented in invertebrates (Simkiss, 1976; Brown, 1982) and the functions of calcium phosphate granules in invertebrates have been reviewed by Simkiss (1976). Two main functions have been described; a skeletal and a dynamic function - such as excretion, storage and Ca mobilisation and/or detoxification - carried out by type $A$ and type $B$ granules, respectively. Type $B$ granules are typically spherical with pronounced layered structures. In invertebrates, only phosphate-rich granules appear to sequester cations (Brown, 1982) and the range of metals that they contain has been interpreted as a system for removing contaminating anions from the body fluids (Simkiss, 1976). As examples, copper-containing granules in crustaceans are clearly used as a store for this element from the blood and represent a mechanism for taking potentially toxic concentration of metal out of circulation; in the same way, zinc-rich granules formation in Balanus balanoides functions as a cellular route for detoxification of heavy metal ions (Simkiss, 1976). In these marine mammals exhibiting high levels of cadmium, these granules could constitute a way of immobilisation and detoxification of the metal.

Nevertheless, the appearance of such stones in human kidneys is always pathological, and could be a sign of the perturbation of calcium metabolism. Thus, a high calcium phosphate excretion resulting of a dysfunction of the tubular reabsorption (Tsalev and Saprianov, 1983; Lauwerys, 1990) as well as an increased prevalence of kidney stones (Lauwerys, 1990; Elinder and Järup, 1996) have been noted after cadmium exposure in human. Some effects of persistent organic pollutants have already been shown in marine mammals, but it is commonly admitted that these species have developed detoxification processes of trace elements allowing them to support very high concentrations (Dietz et al., 1998). The processes are fundamentally direct elimination and/or bioaccumulation of a non-toxic product. In mammals kidney cadmium is mainly bound to metallothioneins, low weight proteins, (Webb and Cain, 1982; Lauwerys, 1990), which are able to prevent organisms from the toxic hazard resulting from a high exposure to this element. Thus, these proteins have been widely studied since their first discovery (Margoshes and Vallee, 1957) and their protective action against cadmium toxicity has been reviewed (Klaassen et al., 1999). Metallothioneins have recently been reviewed in marine mammals and they have been detected in liver and kidney of 10 marine mammal species (Pinnipeds and Odontocetes) (Das et al., 2000). As emphasised 
by the authors, the participation of these proteins in metal detoxification has been investigated since high levels of cadmium have been measured in liver and kidney of marine mammals. They show that the percentage of the cytosolic cadmium bound to metallothioneins can reach almost $100 \%$, that close and dynamic interactions occur between cadmium and these proteins and that those animals can mitigate at least in part, the toxic effect of cadmium.

Nevertheless, a previous study carried out on pilot whales from the Faroe Islands has shown that although cadmium mean concentrations were similar in the liver of two different groups, metallothionein mean concentrations were more than three fold lower in one of them with lower percentage of cadmium bound to the metallothioneins (6 vs. 51\%) (Amiard-Triquet and Caurant 1997). Therefore, the presence of cadmium containing granules in kidney tissue of a wild animal firstly, confirms that cadmium can be found as inorganic form in a mammal kidney and secondly, that detoxification processes could lead to some toxic effects. These toxic effects are all the more conceivable as cadmium is a cumulative element and one can expect a higher frequency of damage in the older individuals of the population. Thus, the older individual exhibiting these granules was only 14 years in this study, whereas the maximum age found in this species was 27 years (Sergeant et al., 1980).

Ultimately, marine consumers have the common task of reducing heavy metals toxicity as a consequence of their high dietary intake, but this study would suggest that long-term effects of cadmium exposure on wild animals cannot be excluded.

\section{Acknowledgements}

We are deeply indebted to Dorete Bloch of the Faroese museum of Natural History for her precious helpful assistance, to Christina Lockyer for the age determination, to the Service Interdisciplinaire de Microscopie et Imagerie Scientifique (SIMIS) of the University of Poitiers for technical support, to Michel Robert and René Boutin from the Centre Commun d'Analyses de 1'Université de la Rochelle, and to Marie-Dominique Appay for her relevant advice.

\section{References}

Amiard-Triquet, C., Caurant, F., 1997. Adaptation des organismes marins à la contrainte métallique: l'exemple du cadmium chez Globicephala melas, mammifère odontocète. Bull. Soc. Zool. Fr. 122(2), 127-136. 
Brown, B.E., 1982. The form and function of metal containing granules in invertebrate tissue. Biol. Rev. 57, 621-667.

Bustamante, P., Caurant, F., Fowler, S.W., Miramand, P., 1998. Cephalopods as a vector for the transfer of cadmium to top marine predators in the north-east Atlantic Ocean. Sci. Total Environ. 220, 71-80.

Caurant, F., Amiard-Triquet, C., 1995. Cadmium contamination in pilot whales Globicephala melas: source and potential hazard to the species. Mar. Pollut. Bull. 30(3), 207-210.

Caurant, F., Amiard, J.C., Amiard-Triquet, C., Sauriau, P.G., 1994. Ecological and biological factors controlling the concentrations of trace elements (As, $\mathrm{Cd}, \mathrm{Cu}, \mathrm{Hg}, \mathrm{Se}, \mathrm{Zn}$ in delphinids Globicephala melas from the north Atlantic Ocean. Mar. Ecol. Prog. Ser. 103, 207-219.

Clarkson, T.W., 1997. The toxicology of mercury. Crit. Rev. Clin. Lab. Sci. 34(3), 369-403.

Das, K., Debacker, V., Bouquegneau, J.M., 2000. Metallothioneins in marine mammals. Cell. Mol. Biol. 46(2), 283-294.

Dietz, R., Riget, F., Johansen, P., 1996. Lead, cadmium, mercury and selenium in Greenland marine animals. Sci. Tot. Environ. 186, 67-93.

Dietz, R., Norgaard, J., Hansen, J.-C., 1998. Have arctic marine mammals adapted to high cadmium levels? Mar. Pollut. Bull. 36(6), 490-492.

Elinder, C., Järup, L., 1996. Cadmium exposure and health risks: recent findings. Ambio 25, 370-373.

Fowler, B.A., 1992. Mechanisms of kidney cell injury from metals. Environ. Health Perspect. $100,57-63$.

Goujon, J.M., Hauet, T., Menet, E., Levillain, P., Babin, Ph., Carretier, M., 1999. Histological evaluation of proximal tubule cell injury in isolated perfused pig kidneys exposed to cold ischemia. J. Surg. Res. 82, 228-233.

Holsbeek, L., Siebert, U., Joiris, C., 1998. Heavy metals in dolphins stranded on the French Atlantic coast. Sci. Tot. Environ. 217, 241-249.

Julshamn, K., Andersen, A., Ringoal, O., Moekore, J., 1987. Trace element intake in the Faroe Islands. I. Element levels in edible parts of pilot whales (Globicephalus melaneus). Sci. Total Environ. 65, 53-62.

Klaassen, C.D., Liu, J., Choudhuri, S., 1999. Metallothionein: an intracellular protein to protect against cadmium toxicity. Annu. Rev. Pharmacol. Toxicol. 39, 267-294.

Lauwerys, R.R., 1990. Le cadmium. Toxicologie Industrielle et Intoxications Professionnelles, 3rd ed. Masson, Paris, pp. 136-149. 
Law, R.J., Fileman, C.F., Hopkins, A.D. et al., 1991. Concentration of trace metals in the livers of marine mammals (seals, porpoises and dolphins) from waters around the British Isles. Mar. Pollut. Bull. 24(6), 296-304.

Law, R.J., Jones, B.R., Baker, J.R., Kennedy, S., Milner, R., Morris, J., 1992. Trace metals in the livers of marine mammals from the Welsh Coast and the Irish Sea. Mar. Pollut. Bull. 24(6), 296-304.

Mackey, E., Demirald, R., Becker, P., Greenberg, R., Koster, B., Wise, S., 1995. Trace element concentrations in cetacean liver tissues archived in the national marine mammals tissue bank. Sci. Total Environ. 175, 25-41.

Margoshes, M., Vallee, B.L., 1957. A cadmium protein from equine kidney cortex. J. Am. Chem. Soc. 79, 4813-4814.

Martoja, R., Viale, D., 1977. Accumulation de granules de séléniure mercurique dans le foie d'Odontocètes (mammifères marins, Cétacés) : un mécanisme possible de détoxication du méthylmercure par le sélénium. Cr. Hebd. Séanc. Acad. Sci., Paris D 285, 109-112.

Moore, M.J., Stegeman, J.J., 1996. Hepatocyte vacuolation and autolytic changes in the liver of pilot whales, Globicephala melas, stranded on Cape Cod, MA, USA. Sci. Total Environ. 186, 105-108.

Nicholson, J.K., Osborn, D., 1983. Kidney lesions in pelagic seabirds with high tissue levels of cadmium and mercury. J. Zool. Lond. 200, 99-118.

Nicholson, J.K., Osborn, D., 1984. Kidney lesions in juvenile starlings Sturnus vulgaris fed on a mercury contaminated synthetic diet. Environ. Pollut. (Series A) 33, 195-206.

Nicholson, J.K., Kendall, M.D., Osborn, D., 1983. Cadmium and mercury nephrotoxicity. Nature 304, 633-635.

Nigro, M., Leonzio, C., 1996. Intracellular storage of mercury and selenium in different marine vertebrates. Mar. Ecol. Prog. Ser. 135, 137-143.

Rawson, A.J., Bradley, J.P., Teetsov, A., Rice, S.B., Haller, E.M., Patton, G.W., 1995. A role for airborne particulate in high mercury levels of some cetaceans. Ecotoxicol. Environ. Saf. 30, 309-314.

Reynolds, E.S., 1963. The use of lead citrate at high $\mathrm{pH}$ as an electron opaque stain in electron microscopy. J. Cell. Biol. 17, 208-212.

Ridgway, S.H., 1972. Mammals of the Sea - Biology and Medecine. Charles C Thomas Publisher, Springfield, IL, USA 812 pp.

Sergeant, D.E., St. Aubin, D.J., Geraci, J.R., 1980. Life history and northwest Atlantic status of the Atlantic white-sided dolphin, Lagenorhyncus acutus. Cetology 37, 1-12. 
Simkiss, K., 1976. Intracellular and extracellular routes in biomineralization. Symposia of the Society for Experimental Biology, vol. 30. University Press, Cambridge, UK, pp. 423444.

Tsalev, D.L., Saprianov, Z.K., 1983. Atomic Absorption Spectrometry in Occupational and Environmental Health Practice, vol. 1. CRC Press, Boca Raton 252 pp.

Wagemann, R., Stewart, R.E.A., Beland, P., Desjardins, C., 1990. Heavy metals and selenium in tissues of beluga whales, Delphinapterus leucas, from the Canadian Arctic and the St Laurent Estuary. Advances in research on the beluga whale, Delphinapterus leucas. Can. Bull. Fish. Aquat. Sci. 224, 191-206.

Webb, M., Cain, K., 1982. Commentary: functions of metallothionein. Biochem. Pharmacol. $31(2), 137-142$. 
Table 1. Characteristics and kidney concentrations of cadmium and mercury in $\mu \mathrm{g} \mathrm{g}^{-1}$ wet weight (wet wt.) of five white-sided dolphins (Lagenorhyncus acutus) caught in the drive fishery of the Faroe Islands and investigated for histopathological study.

\begin{tabular}{llllll}
\hline $\begin{array}{l}\text { Samples } \\
\text { no. }\end{array}$ & Sex & $\begin{array}{l}\text { Age } \\
\text { (years) }\end{array}$ & $\begin{array}{l}\text { Length } \\
(\mathrm{cm})\end{array}$ & $\begin{array}{l}\text { Cadmium } \\
\left(\mu \mathrm{g} \mathrm{g}^{-1} \text { wet wt. }\right)\end{array}$ & $\begin{array}{l}\text { Mercury } \\
\left(\mu \mathrm{g} \mathrm{g}^{-1} \text { wet wt. }^{2}\right.\end{array}$ \\
\hline 1 & $\mathrm{M}$ & 9 & 250 & 22.72 & 1.43 \\
3 & $\mathrm{M}$ & 10 & 250 & 31.07 & 2.54 \\
5 & $\mathrm{~F}$ & $12-14$ & 230 & 24.32 & 1.58 \\
7 & $\mathrm{~F}$ & $<1$ & 130 & 0.02 & 0.12 \\
8 & $\mathrm{M}$ & $<1$ & 125 & 0.02 & 0.15 \\
\hline
\end{tabular}


Table 2. Relative amounts of the different elements identified by energy dispersive X-rays in the middle of granules observed in the basement membrane of the tubules, in the kidney of two adult white-sided dolphin (Lagenorhyncus acutus) caught in the drive fishery of the Faroe Islands.

\begin{tabular}{ll}
\hline Element Atomic & Atomic \% cations \\
\hline $\mathrm{P}$ & 56.9 \\
$\mathrm{Cd}$ & 3.8 \\
$\mathrm{Ca}$ & 39.3 \\
Total & 100 \\
\hline
\end{tabular}




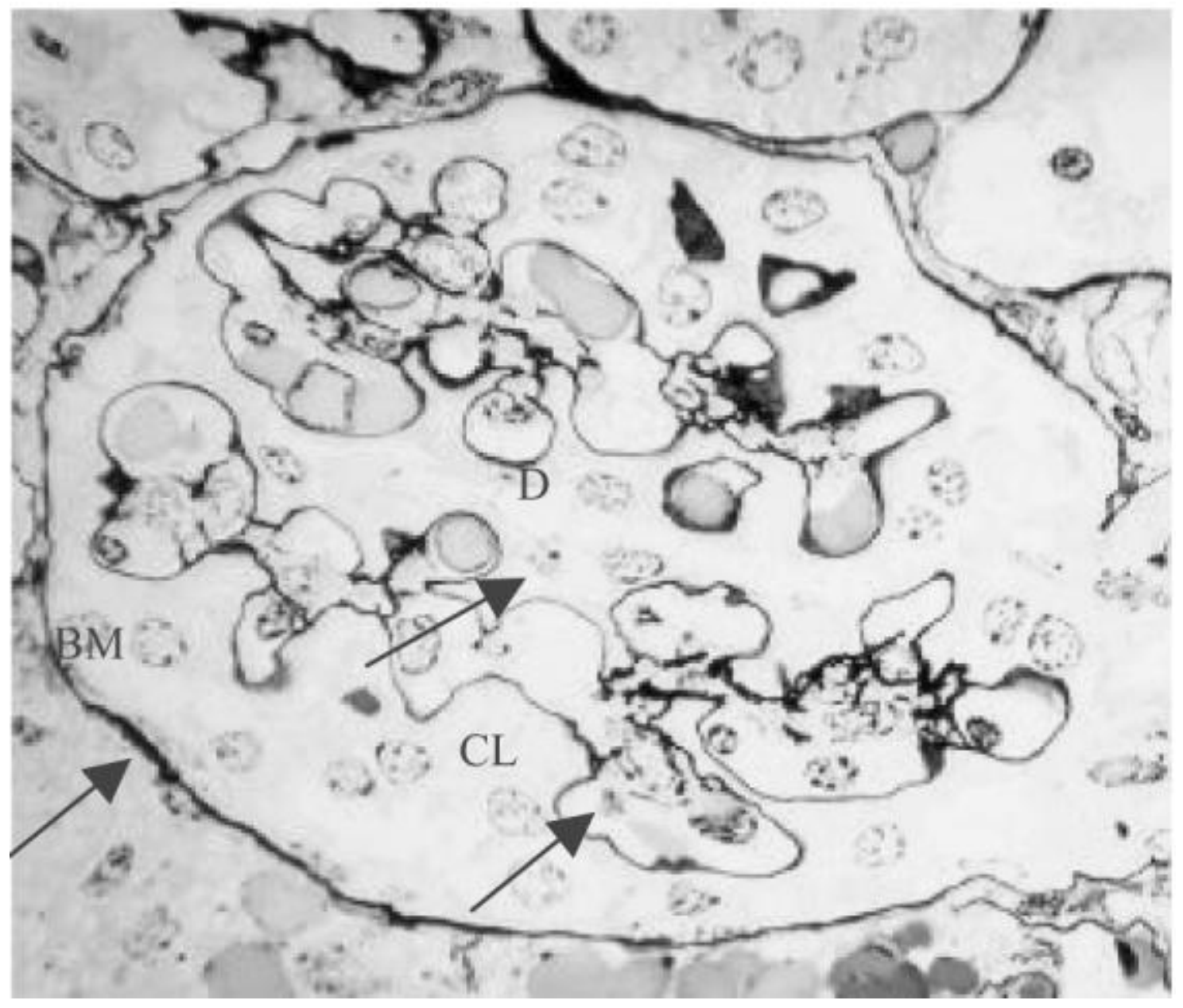

Figure 1. Renal corpuscle of white-sided dolphin (Lagenorhyncus acutus) caught in the drive fishery of the Faroe Islands. Semi-thin section $(1 \mu \mathrm{m})$ stained with Marinozzi, observed in light microscopy (X400). The arrows show the signs of abnormalities: thickening of the basement membrane (BM); a swollen capillary loops (CL); and external debris (D). 

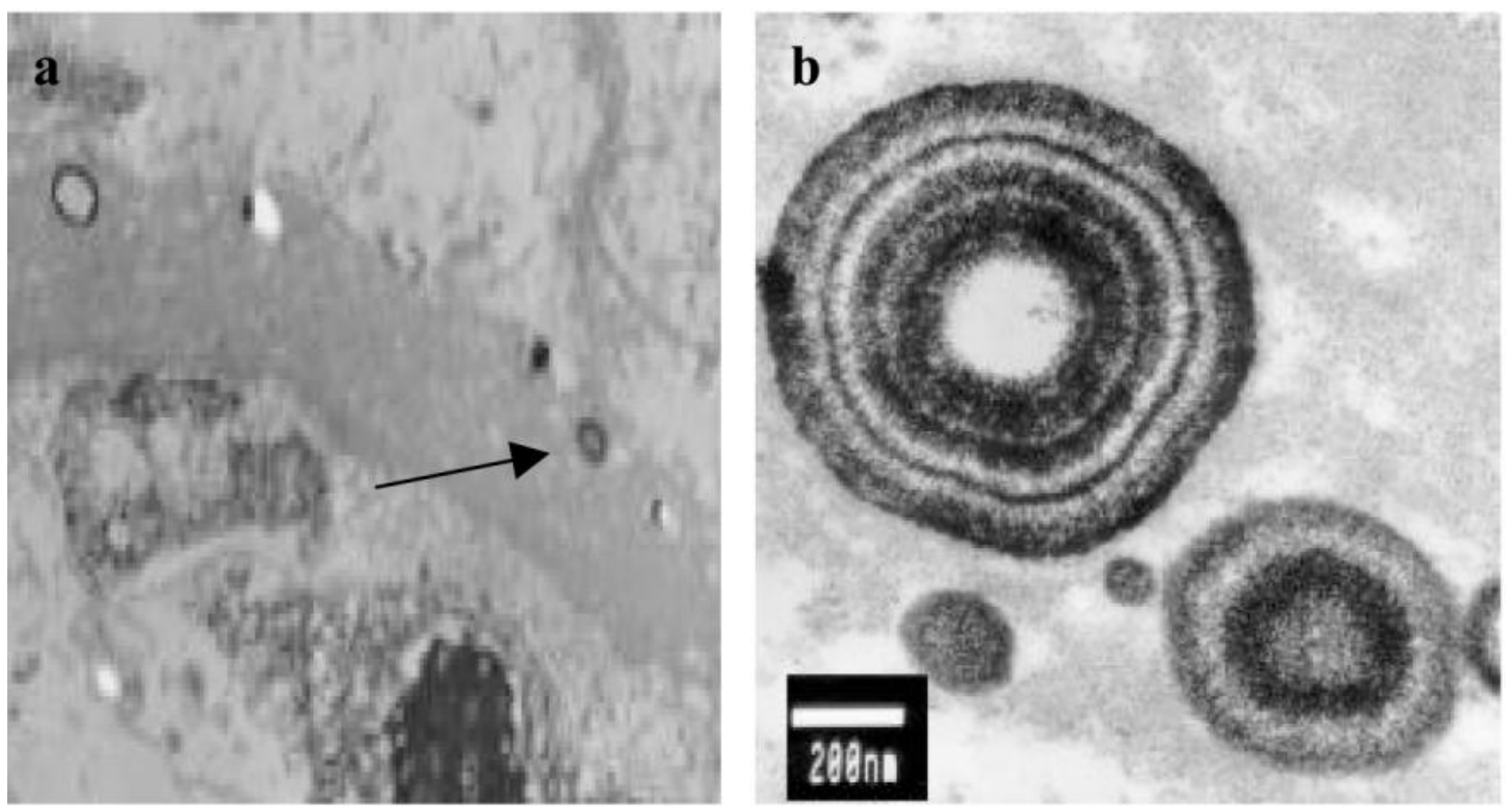

Figure 2. Mineral concretions observed in the basal membrane of the proximal tubule of the kidney of white-sided dolphin (Lagenorhyncus acutus) caught in the drive fishery of the Faroe Islands: (a) X 4000 ; and (b) X 30000 . Thin sections (0.5 $\mu$ m) were stained with uranyl acetate and lead citrate and subsequently, examined with a JEOL-JEM 1010 electron microscope (JEOL, Tokyo, Japan). 